\title{
Antibacterial effect of Ishige okamurae extract against cutaneous bacterial pathogens and its synergistic antibacterial effect against $P$ seudomonas aeruginosa
}

\author{
Bogeum Kim', Min-Sung Kim², ${ }^{2,3}$ Seul-Ki Park', Seok-Chun Ko ${ }^{3}$, Sung-Hwan Eom, Won-Kyo Jung 2,3
} and Young-Mog Kim ${ }^{1,3^{*}}$

\begin{abstract}
Background: Cutaneous bacterial pathogens including Staphylococcus aureus, Staphylococcus epidermidis, Pseudomonas aeruginosa, and Propionibacterium acnes are often involved in acne vulgaris. The currently available therapeutic option for these skin pathogens is an antibiotic treatment, resulting in the emergence of antibiotic-resistant bacteria. The objective of this study was to discover an alternative antibacterial agent with lower side effect from marine algae.

Results: The ethanolic extract of edible brown algae Ishige okamurae exhibits potent antibacterial activity against cutaneous bacterial pathogens. Among the ethanol soluble fractions, the $n$-hexane (Hexane)-soluble fraction exhibited the strongest antibacterial activity against the pathogens with MIC values ranging 64 to $512 \mu \mathrm{g} / \mathrm{mL}$ and with minimum bactericidal concentration values ranging 256 to $2048 \mu \mathrm{g} / \mathrm{mL}$. Furthermore, the combination with Hexane fraction and antibiotics (ceftazidime, ciprofloxacin, and meropenem) exhibited synergistic effect.

Conclusion: This study revealed that the I. okamurae extract exhibited a synergistic antibacterial effect against acnerelated cutaneous bacterial pathogens acquired antibiotic resistant. Thus, the results of the present study suggested that the edible seaweed extract will be a promising antibacterial therapeutic agent against antibiotic-human skin pathogens and its infections.
\end{abstract}

Keywords: Antibacterial effect, Cutaneous pathogens, Ishige okamurae, Pseudomonas aeruginosa

\section{Background}

Opportunistic bacterial pathogens such as Staphylococcus aureus, Staphylococcus epidermidis, Pseudomonas aeruginosa, and Propionibacterium acnes are often associated with cutaneous pathogens (Kim et al. 2017b, a, c). These pathogenic bacteria are often involved in the development of abnormal follicular keratinization and inflammation known acne vulgaris (Yamaguchi et al. 2009; Kim et al. 2017b, a, c). Generally, topical therapeutic option for these cutaneous pathogens is antibiotic treatment to destroy the microbes. However, irrational use of such antibiotics

\footnotetext{
* Correspondence: ymkim@pknu.ac.kr

${ }^{1}$ Department of Food Science and Technology, Pukyong National University,

45, Yongso-ro, Nam-gu, Busan 48513, Republic of Korea

${ }^{3}$ Marine-Integrated Bionics Research Center, Pukyong National University,

Busan 48513, Republic of Korea

Full list of author information is available at the end of the article
}

resulted in antibiotic-resistant bacteria causing treatment failures and fatal outcomes in various infectious diseases (Lee et al. 2014; Kim et al. 2017b, a, c).

Surveillance of $P$. aeruginosa infections has revealed trends of increasing antibacterial resistance, including carbapenem resistance and multidrug resistance (Driscoll et al. 2007). Ceftazidime, carbapenem, or piperacillin resistance rates increased up to $50 \%$ in intensive care unit patients and the multidrug resistance rate, which is resistant to three or more antibiotics, reached 30\% (El Solh and Alhajhusain 2009; Song and Joo 2010). Because of the lack of antibiotics effective against multidrug-resistant $P$. aeruginosa, colistin that has not been used in clinical practice for some time due to toxicity has reappeared and started to be used again ( $\mathrm{Li}$ et al. 2006; Michalopoulos and Karatza 2010). However, new toxicity occurs in more than 
$3 \%$ of patients with the use of colistin, and because of the incompleteness of the drug, multidrug-resistant $P$. aeruginosa has emerged as a clinically significant problem (Paul et al. 2010; Song and Joo 2010).

With increasing the multiple drug-resistant bacteria, it urgently requires a search for new antibacterial substances (Eom et al. 2016a; Eom et al. 2017; Eom et al. 2014). Recently, marine algae have been received attraction as an important source of novel bioactive substances. It has been revealed that marine algae originated compounds exhibiting various biological activities (Wijesekara and Kim 2010; Eom et al. 2016b). Although there are various physiologically active substances in marine algae, there is not much research on the influence of marine algae against cutaneous pathogens. Hence, the present study was aimed at exploiting bioactive compounds of edible marine algae Ishige okamurae against cutaneous pathogens.

I. okamurae, a kind of brown algae with narrow fronds, thick cortical layer, and acute apices, belongs to the family of Ishigeaceae and grows on rocks in the upper and middle intertidal zone on rough open coasts (Cho et al. 2005). The extract of okamurae is known to possess various biological activities such as antioxidant activity (Kim et al. 2008), anti-diabetic activity (Min et al. 2011), anti-obesitic activity (Park et al., 2013), anti-cancer activity (Heo et al. 2012), anti-matrix metalloproteinase activity (Bae et al. 2015), and anti-inflammation (Vo et al. 2011). However, few report is only available on antimicrobial activity of this edible marine algae. The object of this study is to evaluate an antibacterial activity of $I$. okamurae against cutaneous pathogens.

\section{Methods}

\section{Materials and extraction}

The fresh I. okamurae collected from the coastal area of Jeju Island, Korea. The marine algae were washed three times with water to remove salt and foreign materials, and then dried at $50{ }^{\circ} \mathrm{C}$. Dried I. okamurae was finely powdered with a blender (HMF-1000A; Hanil Electronics, Seoul, Korea). The dried sample $(1.0 \mathrm{~kg})$ was extracted with $70 \%$ ethanol $(\mathrm{EtOH} ; 10.0 \mathrm{~L} \times 3$ times) at $70{ }^{\circ} \mathrm{C}$ for $3 \mathrm{~h}$ in triplicate. Then, the solvent was evaporated a using rotary evaporator (Eyela Co., Tokyo, Japan) at $40{ }^{\circ} \mathrm{C}$ in vacuo. The $\mathrm{EtOH}$ extract was suspended in $10 \%$ ethanol and fractionated with $n$-hexane (Hexane; 1 . $0 \mathrm{~L} \times 3$ times), dichloromethane $(\mathrm{CHCl} 3)$, ethyl acetate (EtoAc; $1.0 \mathrm{~L} \times 3$ times), and water solution in order, according to relative polarities. Each fraction was concentrated using the evaporator under vacuum at $45^{\circ} \mathrm{C}$.

\section{Strains and culture conditions}

Type bacterial strains used in this study were from the Korean Collection for Type Cultures (KCTC; Daejeon, Korea) and the American Type Culture Collection (ATCC;
Manassas, VA, USA): S. aureus KCTC 1927, S. epidermidis ATCC 14990, P. aeruginosa KCTC 1637, and P. acnes KCTC 3314. P. aeruginosa clinical isolates were kindly provided by the Gyeongsang National University Hospital (Jinju, Korea), a member of the National Biobank of Korea. S. aureus, S. epidermidis, and P. aeruginosa strains were grown aerobically at $37^{\circ} \mathrm{C}$ in tryptic soy broth (TSB; Difco Inc., Detroit, MI). P. acnes strain was anaerobically cultivated in brain heart infusion broth (BHI; Difco Inc.) supplemented with $1.0 \%$ glucose at $37{ }^{\circ} \mathrm{C}$ for $24 \mathrm{~h}$ in a $\mathrm{CO}_{2}$ incubator (NAPCO 5400; General Laboratory Supply, Pasadena, TX, USA) that was modified with a $10 \%$ $\mathrm{CO}_{2}$ humidified atmosphere.

\section{Measurement of minimum inhibitory concentration (MIC) and minimum bactericidal concentration (MBC)}

The assay of minimum inhibitory concentration (MIC) was followed by the guideline of Clinical and Laboratory Standards Institute (CLSI) (2015). The MIC assay was performed using serial twofold dilution method with Mueller-Hinton broth (MHB; Difco Inc.) and 96-well microtiter plates (with clear flat bottoms). MIC values were determined by reading the plates visually. This test was repeated three times.

The assay of minimum bactericidal concentration (MBC) is the lowest concentration of an antibacterial agent required to kill a particular bacterium (Eom et al. 2017). MBC values were determined by subculturing to agar plates that do not contain the test agent using MIC tested broths. MBC is defined as the lowest concentration of antibacterial agent that reduces the viability of the initial bacterial inoculum by $\geq 99.9 \%$.

\section{Antibiotic susceptibility test (AST)}

AST is used to determine whether an organism is susceptible or resistant to an antimicrobial agent (Jenkins and Schuetz 2012; Kim et al. 2017b, a, c). The antibiotic resistance of test strains was confirmed against four kinds of commercial antibiotics (amikacin, ceftazidime, ciprofloxacin, meropenem; Sigma-Aldrich Co., St. Louis, MO) by MIC assay. An antibiotic was serially diluted and then the bacterial growth was visually checked.

\section{Fractional inhibitory concentration (FIC) assay}

Fractional inhibitory concentration (FIC) assay has been used to evaluate in vitro synergy effect in combination of multiple agents (Hsieh et al. 1993; Odds 2003). In this study, the synergy effect between the Hexanesoluble fraction and antibiotics against $P$. aeruginosa strains exhibiting antibiotic resistance was evaluated. FIC index was calculated using the formula as previously reported (Norden et al. 1979). The FIC was calculated as the minimum inhibitory concentration (MIC) of an antibiotic or the Hexane fraction in combination 
divided by the MIC of the antibiotic or the Hexane fraction A alone.

\section{Results and discussion}

\section{Antibacterial effect of $I$. okamurae extracts against} cutaneous bacterial pathogens

As shown in Table 1, the ethanolic extract of I. okamurae exhibited an antibacterial activity against cutaneous bacterial pathogens in ranging of MIC with 256$512 \mu \mathrm{g} / \mathrm{mL}$. These results suggested that the extract contains an antibacterial substance against human skin bacterial pathogens such as $S$. aureus, S. epidermidis, $P$. aeruginosa, and $P$. acnes. To further investigate the antibacterial activity against the bacterial pathogens, the ethanolic extract was fractioned into Hexane-, $\mathrm{CHCl} 3-$, EtoAc-, and $\mathrm{H}_{2} \mathrm{O}$-soluble fraction as described in the "Methods" section. The antibacterial activity of solvent fractions was then quantitatively evaluated by the MIC assay (Table 2). The MIC values of I. okamurae-soluble fractions were in the range of 64 to $2048 \mu \mathrm{g} / \mathrm{mL}$ against cutaneous pathogens tested in this study. Among these, the Hexane fraction showed the strongest antibacterial activity with the MICs range of 64 to $512 \mu \mathrm{g} / \mathrm{mL}$, followed by the EtoAc fraction, suggesting that an antibacterial substance against the pathogens will abundantly present in the Hexane-soluble fraction. In contrary to other reports that the strongest antibacterial activity of marine algae extracts observed in EtOAc fraction, the Hexane-soluble fraction in I. okamurae extracts exhibited superior antibacterial activity against cutaneous pathogens (Lee et al. 2014; Kim et al. 2016; Kim et al. 2017a).

Table 1 Minimum inhibitory concentration (MIC) of Ishige okamurae extracts against cutaneous bacterial pathogens

\begin{tabular}{|c|c|c|c|c|c|}
\hline \multirow[t]{2}{*}{ Strains } & \multicolumn{5}{|c|}{ MIC $(\mu \mathrm{g} / \mathrm{mL})$} \\
\hline & $\mathrm{EtOH}$ & Hexane & $\mathrm{CHCl} 3$ & EtoAc & $\mathrm{H}_{2} \mathrm{O}$ \\
\hline $\begin{array}{l}\text { Staphylococcus aureus } \\
\text { KCTC } 1927\end{array}$ & 512 & 512 & 512 & 256 & 1024 \\
\hline $\begin{array}{l}\text { Staphylococcus epidermidis } \\
\text { ATCC } 14990\end{array}$ & 512 & 512 & 1024 & 128 & 512 \\
\hline $\begin{array}{l}\text { Propionibacterium acnes } \\
\text { KCTC } 3314\end{array}$ & 512 & 256 & 1024 & 512 & 2048 \\
\hline $\begin{array}{l}\text { Pseudomonas aeruginosa } \\
\text { KCTC } 1637\end{array}$ & 256 & 64 & 256 & 128 & 1024 \\
\hline P. aeruginosa isolate 366 & 256 & 128 & 512 & 128 & 1024 \\
\hline P. aeruginosa isolate 4068 & 256 & 64 & 256 & 128 & 1024 \\
\hline P. aeruginosa isolate 4135 & 512 & 128 & 512 & 128 & 1024 \\
\hline P. aeruginosa isolate 4561 & 512 & 128 & 512 & 512 & 1024 \\
\hline
\end{tabular}

$\mathrm{EtOH}$ ethanol extracts, Hexane $n$-hexane-soluble fraction, $\mathrm{CHCl} 3$ dichloromethane, EtoAc ethyl acetate-soluble fraction, $\mathrm{H}_{2} \mathrm{O}$ water-soluble fraction
Table 2 Minimum bactericidal concentration (MBC) of Ishige okamurae extracts against cutaneous bacterial pathogens

\begin{tabular}{|c|c|c|c|c|c|}
\hline \multirow[t]{2}{*}{ Strains } & \multicolumn{5}{|c|}{$\mathrm{MBC}(\mu \mathrm{g} / \mathrm{mL})$} \\
\hline & $\mathrm{EtOH}$ & Hexane & $\mathrm{CHCl} 3$ & EtoAc & $\mathrm{H}_{2} \mathrm{O}$ \\
\hline $\begin{array}{l}\text { Staphylococcus aureus } \\
\text { KCTC } 1927\end{array}$ & 2048 & 1024 & 2048 & 512 & $>2048$ \\
\hline $\begin{array}{l}\text { Staphylococcus epidermidis } \\
\text { ATCC } 14990\end{array}$ & 2048 & 2048 & 2048 & 512 & $>2048$ \\
\hline $\begin{array}{l}\text { Propionibacterium acnes } \\
\text { KCTC } 3314\end{array}$ & 2048 & 1024 & $>2048$ & 2048 & $>2048$ \\
\hline $\begin{array}{l}\text { Pseudomonas aeruginosa } \\
\text { KCTC } 1637\end{array}$ & 1024 & 256 & 2048 & 512 & $>2048$ \\
\hline P. aeruginosa isolate 366 & 1024 & 256 & 2048 & 1024 & $>2048$ \\
\hline$P$. aeruginosa isolate 4068 & 1024 & 256 & 1024 & 1024 & $>2048$ \\
\hline P. aeruginosa isolate 4135 & 2048 & 512 & 2048 & 1024 & $>2048$ \\
\hline P. aeruginosa isolate 4561 & 2048 & 512 & 2048 & 2048 & $>204$ \\
\hline
\end{tabular}

$\mathrm{EtOH}$ ethanol extracts, Hexane $n$-hexane-soluble fraction, $\mathrm{CHCl} 3$

dichloromethane EtoAc ethyl acetate-soluble fraction, $\mathrm{H}_{2} \mathrm{O}$ water-soluble fraction

In order to evaluate the bactericidal effect of I. okamurae extracts, the $\mathrm{MBC}$ assay was performed (Table 2). The $\mathrm{MBC}$ values of $I$. okamurae fractions were in the range of 512 to above $2048 \mu \mathrm{g} / \mathrm{mL}$ against cutaneous pathogens. Similar to results obtained in the MIC assay, the Hexanesoluble fraction showed superior bactericidal activity in ranges of MBC with 256 to $1024 \mu \mathrm{g} / \mathrm{mL}$. The $\mathrm{MBC}$ values were twofold increased compared to those of MIC values. Similar patterns between MIC and MBC values were reported by several studies (Eom et al. 2014; Kim et al. 2016). Considering both MIC and MBC results, it was concluded that the Hexane-soluble fraction of I. okamurae possess the highest antibacterial activity against cutaneous bacterial pathogens tested in this study. Interestingly, the fraction exhibited strong antibacterial activity against $P$. aeruginosa strains. As mentioned above, $P$. aeruginosa infection is serious problems mainly due to its antibiotic resistance (Driscoll et al. 2007; Michalopoulos and Karatza 2010). In addition, there are few studies on natural substances having antibacterial activity against $P$. aeruginosa strains. Thus, the results obtained in this study strongly indicated that I. okamurae will be a potential candidate to develop an alternative therapeutic agent for the treatment against cutaneous pathogens, specially $P$. aeruginosa infection.

\section{Antibiotic resistance of cutaneous bacterial pathogens}

Antibiotics have been extensively used to treat diseases caused by cutaneous pathogens (Kim et al., 2017b, a, c). However, continued use of these antibiotics caused antibiotic resistance and the emergence of multidrugresistant bacteria (Unemo and Nicholas 2012; Kim et al., 2017b, a, c). In an effort to discover an alternative therapy for antibiotic-resistant bacteria, we evaluated the 
antibiotic susceptibility of cutaneous bacterial pathogens tested in this study. For kinds of antibiotics belong to aminoglycosides, cephalosporins, quinolones, and carbapenems were used for antibiotic susceptibility test (AST). Antibiotic susceptibility or resistance was determined based on the MIC breakpoint values (European Committee on Antimicrobial Susceptibility Testing (EUCAST) 2018).

Among the stains tested in this study, MICs of all strains against amikacin were in the range of the acceptable MIC breakpoint values ranging from 4 to $8 \mu \mathrm{g} / \mathrm{mL}$ indicating susceptibility to the test agent (Table 3 ). In addition, the MIC of S. aureus, S. epidermidis, and $P$. acnes were showed susceptibility against all four antibiotics used in this study. However, some $P$. aeruginosa strains (KCTC1637, isolate 4068, isolate 4135, and isolate 4561 strain) exhibited resistant exceeding the MIC breakpoint against ceftazidime, ciprofloxacin, and meropenemm suggesting that the $P$. aeruginosa strains are multidrug-resistant bacteria (Kim et al., 2017b, a, c).

\section{Synergistic effect between the Hexane-soluble fraction and antibiotics against cutaneous bacterial pathogens}

Since many antibiotic-resistant and multidrug-resistant bacteria have been reported, it has been studied not only the development of new antibiotics or therapies but also the development of alternative therapies in combination

Table 3 Minimum inhibitory concentration (MIC) of antibiotics against cutaneous bacterial pathogens

\begin{tabular}{|c|c|c|c|c|}
\hline \multirow[t]{2}{*}{ Strains } & \multicolumn{4}{|c|}{$\mathrm{MIC}(\mu \mathrm{g} / \mathrm{mL})$} \\
\hline & Amikacin & Ceftazidime & Ciprofloxacin & Meropenem \\
\hline $\begin{array}{l}\text { Staphylococcus } \\
\text { aureus KCTC } \\
1927\end{array}$ & 1 & 2 & 0.5 & 1 \\
\hline $\begin{array}{l}\text { Staphylococcus } \\
\text { epidermidis ACTC } \\
14990\end{array}$ & 1 & 4 & 4 & 1 \\
\hline $\begin{array}{l}\text { Propionibacterium } \\
\text { acnes KCTC } \\
3314\end{array}$ & 4 & 0.5 & 4 & 4 \\
\hline $\begin{array}{l}\text { Pseudomonas } \\
\text { aeruginosa } \\
\text { KCTC1637 }\end{array}$ & 1 & 8 & 8 & 16 \\
\hline $\begin{array}{l}\text { P. aeruginosa } \\
\text { isolate } 366\end{array}$ & 2 & 4 & 4 & 8 \\
\hline $\begin{array}{l}\text { P. aeruginosa } \\
\text { isolate } 4068\end{array}$ & 1 & 16 & 16 & 16 \\
\hline $\begin{array}{l}\text { P. aeruginosa } \\
\text { isolate } 4135\end{array}$ & 1 & 8 & 16 & 8 \\
\hline $\begin{array}{l}\text { P. aeruginosa } \\
\text { isolate } 4561\end{array}$ & 2 & 16 & 16 & 16 \\
\hline MIC breakpoint ${ }^{a}$ & $4-8$ & $1-4$ & $2-8$ & 8 \\
\hline
\end{tabular}

${ }^{a}$ EUCAST European committee on antimicrobial susceptibility testing with using antibacterial materials derived from natural product (Eom et al. 2013; Eom et al. 2016a). As shown in Tables 1 and 2, the Hexane-soluble fraction of $I$. ok murae was presented the highest antibacterial activity against $P$. aeruginosa among the solvent-soluble fractions. Therefore, the Hexane fraction was chosen for investigating a synergy effect with antibiotics in an effort to develop an alternative therapy against multidrugresistant $P$. aeruginosa. The synergistic interaction of Hexane fraction of I. okamurae and antibiotics was tested against $P$. aeruginosa strains by the checkerboard method using FIC assay as stated in the "Methods" section (Hsieh et al. 1993; Odds 2003).

As shown in Table 3, the MICs of ceftazidime, ciprofloxacin, and meropenem against the multidrug-resistant $P$. aeruginosa strains (KCTC1637, isolate 4068, isolate 4135 , and isolate 4561 strain) ranged from 8 to $16 \mu \mathrm{g} /$ $\mathrm{mL}$ exceeding the MIC breakpoint. However, the MICs were dramatically decreased in combination with the Hexane-soluble fraction of I. okamurae. The MICs of ceftazidime against $P$. aeruginosa KCTC 1637 and isolate 4135 strains were reduced, up to $2 \mu \mathrm{g} / \mathrm{mL}$ when applied in combination with the Hexane fraction. In the same way, $P$. aeruginosa isolate 4068 and 4561 strains were reduced up to $4 \mu \mathrm{g} / \mathrm{mL}$. Thus, the MICs decreased twofold in the combination of the Hexane fraction. In addition, the MICs of ciprofloxacin against $P$. aeruginosa strains were reduced two- to threefold in combination with the Hexane fraction. The MICs of meropenem decreased twofold in combination with the Hexane fraction. The median $\Sigma F I C$ of the Hexane fraction-antibiotic combinations against $P$. aeruginosa strains were ranged from 0 . 50 to 0.75 , suggesting that a weak synergistic antimicrobial effect in combination with the Hexane fraction (Eom et al. 2016a; Kim et al., 2017b, a, c) (Table 4).

The results obtained in this study strongly suggested that the Hexane fraction of I. okamurae possess strong antibacterial activity against cutaneous bacterial pathogens. In addition, the fraction showed potent antibacterial activity against multidrug-resistant $P$. aeruginosa that is an important pathogen frequently implicated in healthcareassociated infections and often associated with multidrug resistance (Hirsch and Tam 2010). More interestingly, the fraction exhibited a synergistic effect against multidrugresistant $P$. aeruginosa strains in combination with antibiotics losing its antibacterial activity against the infectious bacteria, suggesting the Hexane-soluble fraction is capable to restore the activity of antibiotics against the multidrugresistant $P$. aeruginosa (Eom et al. 2016a; Kim et al. 2017b). Thus, I. okamurae will be a candidate to overcome multidrug resistance, especially multidrug-resistant $P$. aeruginosa. In order to progress this issue, it will be needed to isolate active compounds from the Hexane-soluble fraction and to elucidate its antibacterial action mechanism. 
Table 4 Fractional inhibitory concentration (FIC) of antibiotics in combination with Hexane-soluble fraction of Ishige okamurae against antibiotic-resistant Pseudomonas aeruginosa

\begin{tabular}{|c|c|c|c|c|c|c|}
\hline Strains & Test compound & $\begin{array}{l}\mathrm{MIC} \\
(\mu \mathrm{g} / \mathrm{mL})\end{array}$ & $\sum \mathrm{FIC}_{\max }$ & $\sum \mathrm{FIC}_{\min }$ & Median $\Sigma F I C$ & $\begin{array}{l}\text { Minimum concentration } \\
\text { for observing synergy }\end{array}$ \\
\hline \multirow{4}{*}{$\begin{array}{l}\text { P. aeruginosa } \\
\text { KCTC } 1637\end{array}$} & Hexane & 64 & 1.06 & 0.31 & 0.57 & 8 \\
\hline & Ceftazidime & 8 & & & & 2 \\
\hline & Hexane & 64 & 1.06 & 0.52 & 0.63 & 8 \\
\hline & Meropenem & 16 & & & & 4 \\
\hline \multirow{6}{*}{$\begin{array}{l}P . \text { aeruginosa } \\
\text { isolate } 4068\end{array}$} & Hexane & 64 & 1.00 & 0.31 & 0.50 & 4 \\
\hline & Ceftazidime & 16 & & & & 4 \\
\hline & Hexane & 64 & 1.06 & 0.38 & 0.57 & 8 \\
\hline & Ciprofloxacin & 16 & & & & 4 \\
\hline & Hexane & 64 & 1.50 & 0.52 & 0.75 & 16 \\
\hline & Meropenem & 16 & & & & 4 \\
\hline \multirow{4}{*}{$\begin{array}{l}P \text {. aeruginosa } \\
\text { isolate } 4135\end{array}$} & Hexane & 128 & 1.13 & 0.38 & 0.63 & 16 \\
\hline & Ceftazidime & 8 & & & & 2 \\
\hline & Hexane & 128 & 1.25 & 0.31 & 0.63 & 16 \\
\hline & Ciprofloxacin & 16 & & & & 4 \\
\hline \multirow{6}{*}{$\begin{array}{l}P . \text { aeruginosa } \\
\text { isolate } 4561\end{array}$} & Hexane & 128 & 1.00 & 0.38 & 0.52 & 8 \\
\hline & Ceftazidime & 16 & & & & 4 \\
\hline & Hexane & 128 & 1.06 & 0.38 & 0.50 & 8 \\
\hline & Ciprofloxacin & 16 & & & & 2 \\
\hline & Hexane & 128 & 1.13 & 0.50 & 0.75 & 32 \\
\hline & Meropenem & 16 & & & & 8 \\
\hline
\end{tabular}

The FIC index indicated synergistic effect: $<0.5$, marked synergy; 0.5 to $<1.0$, weak synergy; 1.0 , additive; $>1.0$ to $<2.0$, subadditivie; 2.0 , indifferent; $>2.0$, antagonistic

$\Sigma F I C_{\text {max }}$ maximum FIC, $\Sigma F I C_{\text {min }}$ minimum $\mathrm{FIC}, \Sigma F I C_{\text {med }}$ medium FIC

\section{Conclusions}

This study was conducted to discover an alternative antibacterial agent with lower side effect from marine algae against cutaneous bacterial pathogens. Edible brown algae $I$. okamurae extract exhibited antibacterial activity against acne-related bacterial pathogens. Among the solvent-soluble fractions of the ethanolic extract, the Hexane-soluble fraction exhibited the strongest antibacterial activity with the lowest MIC values ranging 64 to $512 \mu \mathrm{g} / \mathrm{mL}$. In addition, the combination with Hexane fractions and antibiotics used in acne infection resulted in synergistic antibacterial effect against the antibioticresistant cutaneous bacteria. Thus, I. okamurae can be a potential source of natural product to be used as an effective therapy against skin pathogens.

\section{Abbreviations}

$\sum \mathrm{FIC}_{\text {max }}$ : Maximum $\mathrm{FIC} ; \sum \mathrm{FIC}_{\text {med }}$ : Medium $\mathrm{FIC} ; \sum \mathrm{FIC}_{\text {min }}$ : Minimum $\mathrm{FIC}$ ACTC: The American Type Culture Collection; AST: Antibiotic susceptibility test; $\mathrm{BHI}$ : Brain heart infusion broth; $\mathrm{CHCl}$ 3: Dichloromethane; EtoAc: Ethyl acetate; EtOH: Ethanol extract; FIC: Fractional inhibitory concentration; $\mathrm{H}_{2} \mathrm{O}$ : Water; Hexane: $n$-hexane; KCTC: The Korean Collection for Type Cultures; MBC: Minimum bactericidal concentration; MHB: Mueller-Hinton broth; MIC: Minimum inhibitory concentration; TSB: Tryptic soy broth

\section{Acknowledgements}

The pathogen for this study was provided by the Gyeongsang National University Hospital Branch of National Culture Collection for Pathogens (GNUH-NCCP).

\section{Funding}

This work was supported by a Research Grant of Pukyong National University (year 2017).

\section{Authors' contributions}

BK, MSK, SKP, and SCK designed this study and drafted the manuscript. SHE, WK, and YMK conceived and designed the study, and also revised the manuscript. All authors read and approved the final manuscript.

Ethics approval and consent to participate

Not applicable.

\section{Competing interests}

The authors declare that they have no competing interests.

\section{Publisher's Note}

Springer Nature remains neutral with regard to jurisdictional claims in published maps and institutional affiliations.

\section{Author details}

'Department of Food Science and Technology, Pukyong National University, 45, Yongso-ro, Nam-gu, Busan 48513, Republic of Korea. ${ }^{2}$ Department of Biomedical Engineering, and Center for Marine-Integrated Biomedical Technology (BK21 Plus), Pukyong National University, Busan 48513, Republic of Korea. ${ }^{3}$ Marine-Integrated Bionics Research Center, Pukyong National 
University, Busan 48513, Republic of Korea. ${ }^{4}$ Department of Food Science and Technology, Dongeui University, Busan 47340, Republic of Korea.

Received: 8 January 2018 Accepted: 6 April 2018

Published online: 18 July 2018

\section{References}

Bae MJ, Karadeniz F, Ahn BN, Kong CS. Evaluation of effective MMP inhibitors from eight different brown algae in human fibrosarcoma HT1080 cells. Prev Nut Food Sci. 2015;20:153-61.

Cho JY, Choi JS, Kang SE, Kim JK, Shin HW, Hong YK. Isolation of antifouling active pyroglutamic acid, triethyl citrate and di-n-octylphthalate from the brown seaweed Ishige okamurae. J Appl Phycol. 2005:17:431-5.

Clinical and Laboratory Standards Institute (CLSI). Methods for dilution antimicrobial susceptibility tests for bacteria that grow aerobically; approved standard, 10th ed. Wayne: Clinical and Laboratory Standards Institute; 2015.

Driscoll JA, Brody SL, Kollef MH. The epidemiology, pathogenesis and treatment of Pseudomonas aeruginosa infections. Drugs. 2007;67:351-68.

El Solh AA, Alhajhusain A. Update on the treatment of Pseudomonas aeruginosa pneumonia. J Antimicrob Chemother. 2009;64:229-38.

Eom SH, Jung YJ, Lee DS, Yim MJ, Kim HS, Lee SH, Myeong J, Lee J, Kim HW, Kim KH, Lee MS, Kim YM. Studies on antimicrobial activity of Poncirus trifoliata ethyl extract fraction against methicillin-resistant Staphylococcus aureus and to elucidate its antibacterial mechanism. J Environ Biol. 2016a;37:129-34.

Eom SH, Kang SK, Lee DS, Myeong Jl, Lee J, Kim HW, Kim KH, Je JY, Jung WK, Kim YM. Synergistic antibacterial effect and antibacterial action mode of chitosan-ferulic acid conjugate against methicillin-resistant Staphylococcus aureus. J Microbiol Biotechnol. 2017;26:784-9.

Eom SH, Kim DH, Lee SH, Yoon NY, Kim JH, Kim TH, Chung YH, Kim SB, Kim YM, Kim HW, Lee MS, Kim YM. In vitro antibacterial activity and synergistic antibiotic effects of phlorotannins isolated from Eisenia bicyclis against methicillin-resistant Staphylococcus aureus. Phytother Res. 2013;27:1260-4.

Eom SH, Lee DS, Jung YJ, Park JH, Choi Jl, Yim MJ, Jeon JM, Kim HW, Son KT, Je $J Y$, Lee MS, Kim YM. The mechanism of antibacterial activity of phlorofucofuroeckol-A against methicillin-resistant Staphylococcus aureus. Appl Microbiol Biotechnol. 2014;98:9795-804.

Eom SH, Lee EH, Park K, Kwon JY, Kim PH, Jung WK, Kim YM. Eckol from Eisenia bicyclis inhibits inflammation through the Akt/NF-KB signaling in Propionibacterium acnes-induced human keratinocyte HaCat cells. J Food Biochem. 2016b:41:e12312.

European Committee on Antimicrobial Susceptibility Testing(EUCAST) Retrieved from http://www.eucast.org on January 3, 2018.

Heo SJ, Cha SH, Kim KN, Lee SH, Ahn G, Kang DH, Oh C, Choi YU, Affan A, Kim D, Jeon YJ. Neuroprotective effect of phlorotannin isolated from Ishige okamurae against $\mathrm{H} 2 \mathrm{O} 2$-induced oxidative stress in murine hippocampal neuronal cells, HT22. Appl Biochem Biotechnol. 2012;166:1520-32.

Hirsch EB, Tam VH. Impact of multidrug-resistant Pseudomonas aeruginosa infection on patient outcomes. Expert Rev Pharmacoecon Outcomes Res. 2010;10:441-51.

Hsieh MH, Yu CM, Yu VL, Chow JW. Synergy assessed by checkerboard. A critical analysis. Diagn Microbiol Infect Dis. 1993;16:343-9.

Jenkins SG, Schuetz AN. Current concepts in laboratory testing to guide antimicrobial therapy. Mayo Clin Proc. 2012;87:290-308.

Kim JH, Yu D, Eom SH, Kim SH, Oh J, Jung WK, Kim YM. Synergistic antibacterial effects of chitosan caffeic acid conjugate against antibiotic resistant acne related bacteria. Mar Drugs. 2017b;15:E167.

Kim KH, Eom SH, Yu D, Kim HJ, Kim DH, Song HS, Kim DM, Kim YM. Fucofuroeckol-A from edible marine alga Eisenia bicyclis to restore antifungal activity of fluconazole against fluconazole-resistant Candida albicans. J Appl Phycol. 2017a; https://doi.org/10.1007/s10811-017-1232-1

Kim SH, Eom SH, Yu D, Lee MS, Kim YM. Oligochitosan as a potential anti-acne vulgaris agent: combined antibacterial effects against Propionibacterium acnes. Food Sci Biotechnol. 2017c;26:1029-36.

Kim YA, Kong CS, Um YR, Im Lee J, Nam TJ, Seo Y. Antioxidant efficacy of extracts from a variety of seaweeds in a cellular system. Ocean Sci J. 2008:43:31-7.

Kim YH, Kim JH, Kim DH, Kim SH, Kim HR, Kim YM. Synergistic antimicrobial effect of Sargassum serratifolium (C. Agardh) C. Agardh extract against human skin pathogens. Korean J Food Sci Technol. 2016;48:241-6.

Lee JH, Eom SH, Lee EH, Jung YJ, Kim HJ, Jo MR, Son KT, Lee HJ, Kim JH, Lee MS, Kim YM. In vitro antibacterial and synergistic effect of phlorotannins isolated from edible brown seaweed Eisenia bicyclis against acne-related bacteria. Algae. 2014:29:47-55.

Li J, Nation RL, Turnidge JD, Milne RW, Coulthard K, Rayner CR, Paterson DL. Colistin: the re-emerging antibiotic for multidrug-resistant gram-negative bacterial infections. Lancet Infect Dis. 2006;6:589-601.

Michalopoulos AS, Karatza DC. Multidrug-resistant gram-negative infections: the use of colistin. Expert Rev Anti-Infect Ther. 2010;8:1009-17.

Min KH, Kim HJ, Jeon YJ, Han JS. Ishige okamurae ameliorates hyperglycemia and insulin resistance in C57BL/KsJ-db/db mice. Diabetes Res Clin Pract. 2011;93:70-6.

Norden CW, Wentzel H, Keleti E. Comparison of techniques for measurement of in vitro antibiotic synergism. J Infect Dis. 1979;140:629-33.

Odds FC. Synergy, antagonism, and what the chequerboard puts between them. J Antimicrob Chemother. 2003;52:1.

Park SJ, Jeon YJ, Kim HJ, Han JS. Anti-obesity effects of Ishige okamurae extract in C57BL/6J mice fed high-fat diet. Korean J Food Sci Technol. 2013:45:199-205.

Paul M, Bishara J, Levcovich A, Chowers M, Goldberg E, Singer P, Lev S, Leon P, Raskin M, Yahav D, Leibovici L. Effectiveness and safety of colistin: prospective comparative cohort study. J Antimicrob Chemother. 2010;65:1019-27.

Song $\mathrm{JH}$, Joo EJ. The crisis of antimicrobial resistance: current status and future strategies. J Korean Med Assoc. 2010;53:999-1005.

Unemo M, Nicholas RA. Emergence of multidrug-resistant, extensively drugresistant and untreatable gonorrhea. Future Microbiol. 2012;7:1401-22.

Vo TS, Kim JA, Wijesekara I, Kong CS, Kim SK. Potent effect of brown algae (Ishige okamurae) on suppression of allergic inflammation in human basophilic KU812F cells. Food Sci Biotech. 2011;20:1227-34.

Wijesekara I, Kim SK. Angiotensin-I-converting enzyme (ACE) inhibitors from marine resources: prospects in the pharmaceutical industry. Mar Drugs. 2010; 8:1080-93.

Yamaguchi N, Satoh-Yamaguchi K, Ono M. In vitro evaluation of antibacterial, anticollagenase, and antioxidant activities of hop components (Humulus lupulus) addressing acne vulgaris. Phytomedicine. 2009;16:369-76.

\section{Ready to submit your research? Choose BMC and benefit from:}

- fast, convenient online submission

- thorough peer review by experienced researchers in your field

- rapid publication on acceptance

- support for research data, including large and complex data types

- gold Open Access which fosters wider collaboration and increased citations

- maximum visibility for your research: over $100 \mathrm{M}$ website views per year

At BMC, research is always in progress.

Learn more biomedcentral.com/submissions 